\title{
Pesan Damai Al-Qur'an: Upaya Menumbuhkan Kesadaran Multikultural
}

\begin{abstract}
Abstrac
This article is a library research in which the data is analyzed qualitatively.This writing focuses on the importance of multicultural education as an effort to keep the religious harmony as a representation of multicultural society. Multicultural education as the basis of education values cultural diversity. Whereas, the religious education is as a basis of education on religious values to produce religious men. The combination of these two concepts of education aims to make an educational system that integrates from both of them, or reduce the advantages, especially to produce religious humanist in a good character.
\end{abstract}

Keywords: Ta'aruf, Tasamauh, Europhasentrism, Skripturalis

\begin{abstract}
Abstrak
Tulisan ini merupakan kajian pustaka yang mana faktanya telah dianalisa secara kualitatif. Tulisan ini focus terhadap pentingnya pendidikan multicultural sebagai upaya untuk mempertahankan kerukunan umat beragama sebagai potret masyarakat yang multikultur. Pendidikan multikultural sebagai basis pendidikan yang menghargai kemajemukan budaya sedangkan pendidikan agama sebagai basis pendidikan yang bersumberkan pada nilai-nilai keagamaan untuk melahirkan manusia-manusia religius. Perpaduan dua konsep pendidikan ini bertujuan untuk dapat membangun sistem pendidikan yang dapat mengintegrasikan dari keduanya atau mengurangi kelemahannya, khususnya untuk mewujudkan karakter yang humanis dan religious
\end{abstract}

Kata Kunci: Ta'aruf, Tasamauh, Eropasentrisme, Skripturalis

Saifuddin

Dosen FAI Universitas Islam Mojopait Mojokerto

Saifuddin@gmail.com 


\section{A. Pendahuluan}

Kehadiran agama adalah untuk memberi petunjuk kepada penganutnya tentang bagaimana cara hidup dan menjalani kehidupan dengan "baik". Adalah sebuah fakta, bahwa agama tidak hanya satu. Ada beragam agama yang menghiasi sejarah kehidupan umat manusia. Namun dalam kenyataannya tidak jarang kehidupan umat beragama diwarnai dengan ketegangan antara penganut agama satu dengan lainnya. Ketegangan antar pemeluk agama sering terjadi akibat penafsiran pemeluknya terhadap agama yang dianutnya. Pemeluk agama mempunyai klaim kebenaran sendiri terhadap agamanya masing-masing. Sering, ketegangan itu berujung pada konflik dan bahkan peperangan. Perselisihan di antara pemeluk agama muncul akibat klaim kebenaran eksklusif atas wahyu keselamatan yang dimiliki. Klaim eksklusif merupakan penegasan jatidiri suatu kelompok agama untuk membedakan dengan kelompok agama lain. Kemudian yang terjadi adalah, suatu kelompok agama berusaha menunjukkan eksistensi dirinya dengan cara memaksakan klaim keselamatan eksklusif kepada kelompok lain yang juga mempunyai konsep keselamatan sendiri. Adanya klaim kebenaran eksklusif inilah yang kemudian memunculkan ketegangan antar umat beragama.

Diantara agenda besar kehidupan manusia dewasa ini adalah terwujudnya persatuan dan kesatuan masyarakat dalam membangun kesejahteraan hidup bersama — dalam bingkai kehidupan yang bermartabat dan saling menghormati hak-hak setiap individu yang terdiri dari keyakinan agama yang beragam. Tidaklah ringan tantangan yang dihadapi dalam mewujudkan tata kehidupan yang berkeadaban yang ditandai dengan keharmonisan hubungan antar agama dan kerukunan antar umat beragama. Kerukunan antar umat beragama akan sulit terwujud jika paham eksklusivisme beragama masih dominan. Eksklusivisme merupakan paham yang menganggap bahwa pandangan atau ide dari kelompoknya saja yang dianggap paling benar sementara pandangan atau ide dari kelompok lain dianggap salah. Pandangan ini disandarkan pada sebuah klaim yang 


\section{Pesan Damai Al-Qur'an}

terdapat pada masing-masing agama. Pada dasarnya klaim eksklusivisme sudah selayaknya menjadi bagian integral dari setiap umat beragama, karena hanya dengan mengerti dan mematuhi perintah agama yang terdapat dalam kitab suci seorang pemeluk agama dikatakan telah menjalankan praktik keagamaan dengan baik. Namun, yang terjadi adalah eksklusivisme mempunyai dampak yang kurang baik. Paham keagamaan tersebut sangat rentan bersinggungan dengan intervensi dan kepentingan politik. Kemudian, yang terjadi adalah, eksklusivisme justru menjadikan pandangan keagamaan yang membatasi pergaulan dan pergulatan dengan paham keagamaan yang lain. Banyak kaum beragama terjebak pada paham monisme, sebuah paham yang menganggap hanya ada satu jalan menuju kebenaran. Jalan kebenaran lain dengan sendirinya akan ditolak.

Setiap tradisi keagamaan dibentuk oleh kultur, pengalaman, pemikiran dan spiritualitas yang berbeda-beda. Setiap tradisi religious adalah baik selama ia memberikan pengaruh moral dan spiritual pada para pengikutnya.

Tulisan ini hendak menyajikan argumen bahwa Islam adalah agama pembawa kedamaian. Dalam kitab suci Alquran terdapat pesan-pesan kedamaian dalam bingkai kerukunan dan toleransi. Menggali pesan kedamaian dalam teks suci, dewasa ini, dirasa sangat perlu dan mendesak. Konflik manusia yang dilatar belakangi perbedaan pandangan keagamaan masih marak terjadi di mana-mana. Tidak hanya antar penganut satu agama dengan agama lain konflik terjadi, bahkan antar faksi/kelompok dalam satu agama yang berbeda pandangan atau penafsirannya konflik bisa tersulut. Atas dasar itu, memunculkan kembali pesan-pesan kitab suci tentang kerukunan dan perdamaian merupakan kebutuhan dalam rangka menumbuhsuburkan kesadaran akan pentingnya kerukunan dan toleransi dalam masyarakat yang mudah terpecah akibat perbedaan keyakinan.

\section{B. Perdamaian dalam Islam}

Untuk memahami bahwa Islam adalah agama yang mendambakan perdamaian, cukuplah hanya dengan memahami makna dari nama agama ini. "Islam”. Atau cukup dengan mendengar ucapan yang dianjurkan dalam 
setiap pertemuan individu atau kelompok dengan lainnya. "Assalamu 'alaykum". Sapaan lazim yang biasa diucapkan kaum muslimin tersebut bermakna "keselamatan untuk/bagi anda". Dengan memahami perihal di atas, kita dapat menghayati bahwa kedamaian yang dicitakan dalam Islam bukan hanya untuk diri pribadi tapi juga bagi pihak lain. Terkait denagn hal ini Rasulullah SAW. Bersabda bahwa pribadi seorang muslim adalah "siapa yang menyelamatkan orang lain/muslimun (yang juga mendambakan perdamaian) dari gangguan lisan dan lidahnya". Perdamaian adalah ciri utama dari ajaran agama Islam.

Hanya berangkat dari term "Islam",lahirnya keharusan adanya perdamaian bagi seluruh makhluk adalah sebuah hal yang seharusnya diperjuangkan. Tidak dapat disangkal bahwa dalam Alquran sendiri terdapat beberapa ayat yang memerintahkan untuk berperang. Keadaan ini mengharuskan untuk mempersiapkan kekuatan guna menangkal kekuatan musuh. Namun perlu diperhatikan bahwa mempersiapkan diri untuk berperang dan menggunakan cara kekerasan dalam Islam adalah untuk menakut-nakuti mereka yang bertujuan untuk membuat kekacauan dan disintegrasi. Seandainyapun peperangan tidak dapat dielakkan maka keadaan itu hanya boleh dilakukan untuk menyingkirkan penganiayaanitupun dalam batas-batas tertentu. Anak-anak, orang tua, kaum lemah, bahkan pepohonan harus dilindungi. Dan apabila pihak musuh sudah berubah sikap untuk menuju perdamaian maka harus diikuti pula kecenderungan berdamai itu sesuai dengan perintah yang tercantum dalam surah al-Anfal ayat ke 61:

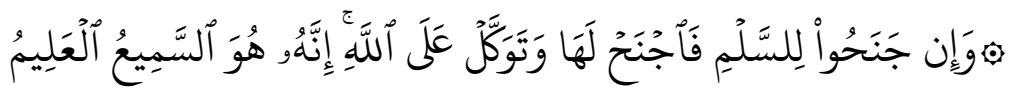

"kalau mereka cenderung kepada perdamaian maka sambutlah kecenderungan itu, dan berserah dirilah kepada Allah".

Nurkholis Madjid mengatakan "perang yang benar, perang di jalan Tuhan, adalah perang yang menghasilkan kelestarian agama-agama dan budaya-budaya sebagaimana yang dilambangkan dalam dalam keutuhan 


\section{Pesan Damai Al-Qur'an}

pranata-pranata keagamaan. Jika muncul ancaman untuk menghancurkan suatu agama, termasuk budaya yang benar dan bermanfaat untuk manusia maka Allah akan "turun tangan" memenangkan pihak yang benar dan membela kebenaran, mereka yang membela Allah".Dengan demikian, nilainilai yang dikembangkan oleh ajaran agama Islam adalah menghindari cara kekerasan. Tetapi apabila cara kekerasan sudah tidak dapat dihindarkan, maka perlu diperhatikan sesungguhnya cara kekerasan hanya digunakan untuk menghindari kekerasan dan penindasan. Sehingga cara kekerasan sebenarnya adalah untuk menghidupkan suasana damai dalam masyarakat yang tercermin dalam sikap saling menghargai walaupun berbeda pandangan keagamaan.

Terkait dengan ajaran universal Alquran tentang perdamaian, dalam surah al-Hajj ayat ke 40 dinyatakan

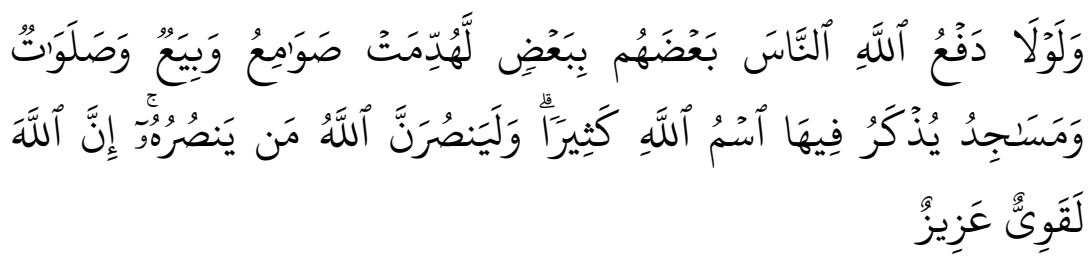

"seandainya Allah tidak menolak keganasan sebagian atas sebagian yang lain (tidak mendorong kerjasama antar manusia) niscaya robohlah biara-biara, gereja-geraja, sinagog-sinagog dan masjid-masjid, yang di dalamnya banyak disebut nama Allah.

Menyikapi ayat ini beberapa Ulama menyatakan pendapatnya. Thahir Ibn 'Asyur mengatakan seandainya tidak ada pembelaan manusia terhadap tempat ibadah kaum muslimin, niscaya kaum musyrikin akan melampaui batas sehingga melakukan agresi pula terhadap negeri-negeri tetangga mereka yang penduduknya menganut agama selain Islam yang juga bertentangan dengan kaum musyrikin dalam rangka menghilangkan ajaran tauhid. Sedangkan Thabathaba'i menyatakan walaupun konteks ayat tersebut adalah penjelasan tentang sebab disyariatkannya perang dan jihad yang bertujuan memelihara masyarakat agamis dari agresi musuh agama yang berupaya memadamkan nur ilahi. Namun cakupan makna yang dapat 
digali adalah semua upaya pembelaan terhadap kemanfaatan manusia serta kemaslahatan hidupnya. Pembelaan ini-menurut Thabathaba'I—adalah sunnah fithriyah yang tertancap dalam jiwa manusia.

Disini sekali lagi ditekankan bahwa perang adalah upaya terakhir yang harus ditempuh apabila jalan lain mengalami jalan buntu. Manusia harus merelakan dirinya (termasuk nyawanya) untuk berkorban guna mewujudkan tatanan sosial masyarakat yang berkeadilan dan menghilangkan penindasan. Anjuran berperang dalam sejarah perjuangan Rasulullah adalah untuk menghindari agresi dan penyiksaan yang dilakukan orang-orang musyrik terhadap pengikut-pengikut Rasul. Seperti yang tertuang dalam surah al-Baqarah "dan perangilah mereka sehingga tidak ada lagi fitnah (penyiksaan yang keji).

\section{Alquran dan Keniscayaan Masyarakat Multikultural}

Sebagai sebuah kitab suci yang menjadi pedoman umat Islam dalam segala aspek kehidupan, Alquran menjelaskan bahwa keragaman dalam kehidupan manusia adalah keniscayaan yang tak bisa dihindari. Untuk mewujudkan tata-kehidupan yang damai dan saling menghormati umat Islam perlu kiranya menggali kembali khazanah luhur konsep masyarakat multicultural yang terkandung dalam kitab sucinya. Diantara nilai- nilai multicultural yang terkandung dalam Alquran adalah:

\section{Toleransi}

Kata toleransi sendiri dalam bahasa Arab biasa dikenal dengan istilah at-Tasamuh. at-Tasamuh kemudian menjadi konsep dasar dan karakter ajaran Islam yang ramah dan menghargai perbedaan sehingga Islam wajar disebut sebagai agama kasih sayang (din ar-rahmah wa assamahah). Sebaliknya, orang yang menghalang-halangi dan mempersulit pihak lain untuk mengekspresikan dan menjalankan keyakinannya, atau bahkan bersikap kasar serta melancarkan kekerasan verbal ataupun fisik terhadap pihak yang berseberang dengannya adalah sikap intoleran. 


\section{Pesan Damai Al-Qur'an}

Konsep toleransi apabila merujuk pada kitab suci Alquran maka akan banyak ditemukan ayat-ayat yang secara substansial membahas tentang toleransi. Perbedaan yang ada dalam kehidupan manusia dalam arti keragaman dalam banyak aspek kehidupan adalah kehendak Allah. Kehendak Allah yang biasa dikenal dengn istilah sunnatullah. Ayat-ayat Alquran yang membahas tentang toleransi diantaranya adalah ayat ke48 dari surat al-Maidah:

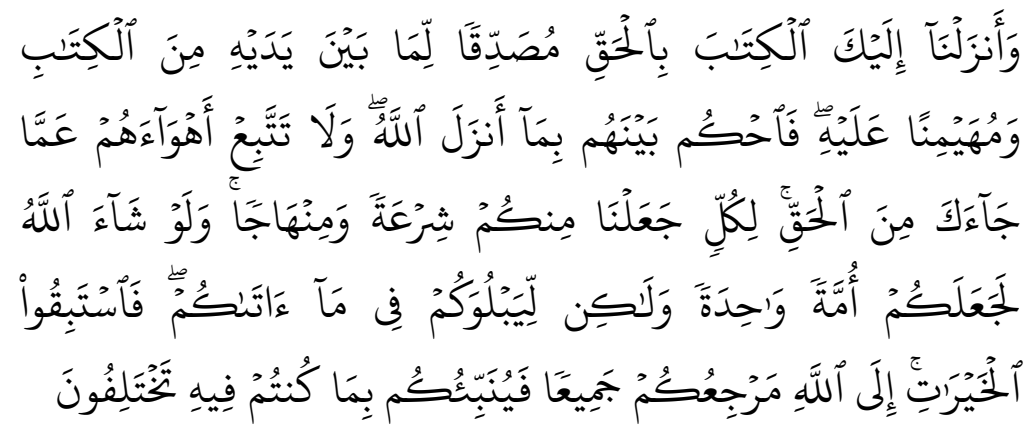

"Dan Kami telah turunkan kepadamu Al- Quran dengan haq, membenarkan apa yang sebelumnya, dari Kitab-Kitab dan batu ujian terhadapnya; maka putuskanlah (perkara) di antara mereka menurut apa yang Allah turunkan dan janganlah engkau mengikuti hawa nafsu mereka dengan (meningglalkan kebenaran) yang telah datang kepadamu. Bagi masing-masing, Kami berikan aturan dan jalan yang terang. Sekiranya Allah menghendaki, niscaya Dia menjadikan kamu satu umat (saja), tetapi Dia hendak menguji kamuterhadap yang telah diberikanNya kepadamu, maka berlomba-lombalah terhadap aneka kebajikan. Hanya kepada Allahlah kembali kamu semuanya, lalu Dia memberitahukan kepada kamu apa yang kamu telah berselisih dalam menghadapinya."

Dari ayat ini bisa kita tarik benang merah, bahwa kemajemukan merupakan sunnatullah. Ada beberapa latar belakang (sabab nuzul) turunnya ayat di atas di antaranya yang ditandaskan oleh pakar tafsir kenamaan Ibnu Katsir, yaitu adalah riwayat dari Ibnu Jarir yang melaporkan bahwa ada seorang laki-laki memiliki dua anak yang menganut agama Nasrani. Laki-laki tersebut memaksa anaknya untuk memluk Islam, namun keduanya menolak dan bertahan dengan 
keyakinannya sebagai penganut Nasrani. Kemudian ayat ini turun, yang sebenarnya melarang melakukan pemaksaan dalam masalah agama.

Ayat di atas memberikan kesan bahwa kehidupan bertoleransi haruslah diemplementasikan berdasarkan sikap adil tanpa melihat latar belakang agama. Hal ini diperkuat dengan pandangan pakar tafsir Indonesia, Quraish Shihab. Dengan mengutip Thahir Ibnu 'Asyur, dijelaskan bahwa Rasul saw. menghadapi dua pihak bersengketa yang masing-masing memiliki argument kuat. Ketika itu Rasul saw. diperingatkan agar jangan sampai keinginan atau hawa nafsu satu pihak yang menjadi dasar penguatan dan pemenangannya. Dengan alas an Rasul saw. sangat ingin agar semua orang memeluk Islam, boleh jadi dengan member putusan yang mendukung salah satu pihak, dapat mendorong mereka untuk beriman. Penggalan ayat tersebut mengingatkan Rasul agar jangan sampai keinginan beliau itu mengantar kepada pengabaian upaya sungguh-sungguh untuk menetapkan hukum yang adil, karena tegaknya hukum dengan adil adalah lebih utama dari pada memperbanyak orang memeluk Islam.

Dari petikan ayat di atas, dunia dihuni oleh umat yang beraneka ragam pandangan dan pola pikir, sudah sepatutnya saling menghargai jalan yang dipilih masing. Setiap individu berhak memilih dan menjalankan agama yang diyakininya, karena ia sendirilah yang bertanggung jawab penuh atas apa yang telah menjadi pilihannya.

\section{Persamaan Derajat}

Adalah sebuah keniscayaan yang tak bisa dihindari bahwa manusia hidup di dunia ini diciptakan beragam. Dalam diri manusia terdapat perbedaan warna kulit, jenis kelamin, suku, bahasa, ras dan golongan. Kenyataan tersebut adalah mutlak kehendak Allah, sebagaimana kita mendapati dalam alam semesta ini penciptaan Allah yang beraneka ragam. Adanya perbedaan yang ada bukanlah dimaksudkan agar manusia berpecah belah, berselisih satu sama lain, merendahkan satu dengan lainnya, saling bermusuhan, namun perbedaan yang ada 


\section{Pesan Damai Al-Qur'an}

dijadikan agar manusia saling mengenal, melengkapi dan memahami antara satu dengan lainnya.

Tinggi rendahnya kedudukan manusia tidaklah ditentukan oleh warna kulit, jenis kelamin, suku, bahasa, ras, asal-usul keturunan dan golongan serta karakteristik fisik lainnya, tetapi ditentukan oleh kualitas diri dan spiritualnya. Semua manusia berkedudukan dan berderajat sama, satu-satunya pembeda adalah kadar ketaqwaannya. Alquran telah dengan tegas mewacanakan tentang keragaman. Alquran berbicara tentang harkat dan martabat manusia yang setara tanpa membandingkan satu dengan lainnya. Sebagaimana hal ini dinyatakan dalam surat alHujurat ayat ke-13

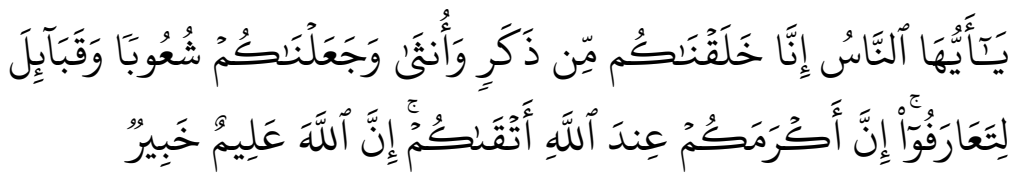

"Hai manusia, sesungguhnya Kami menciptakan kamu dari seorang laki-laki dan seorang perempuan serta menjadikan kamu berbangsa-bangsa, juga bersuku-suku supaya kamu saling mengenal. Sesungguhnya yang paling mulia diantara kamu di sisi Allah ialah yang paling bertakwa diantara kamu. Sesungguhnya Allah Maha Mengetahui lagi Maha Mengenal".

Kondisi dimana masyarakat "saling mengenal" atau "ta'aruf" adalah merupakan prasyarat penting bagi terciptanya suasana rukun untuk dapat hidup bersama dengan latar belakang yang berbeda. Masyarakat yang "ta'aruf" adalah merupakan indikasi positif dalam suatu masyarakat plural untuk dapat hidup bersama, saling menghormati, dan saling menerima perbedaan yang ada diantara mereka. Dengan segala implikasinya, "ta'aruf” menjadi gerbang cultural yang membuka akses bagi langkah-langkah berikutnya dalam membangun kebersamaan dalam mengarungi kehidupan cultural melalui karakter inklusif yang ada seperti; toleransi (tasamuh), moderat (tawasuth), tolong menolong ta'awun), dan kehidupan harmonis 
(tawazun). Karakter masyarakat tersebut menurut Tholhah Hasan disebut dengan akar-akar nilai inklusif dari multikulralisme Islam.

Dengan mengutip pendapat Fahruddin al-Razy yang terkenal dengan Tafsir al-Kabirnya, Tholhah Hasan menjabarkan kata lita'arafu dalam ayat ke-13 surat al-Hujurat adalah kesediaan dari anggota masyarakat untuk saling mengenal tidak boleh dihambat oleh perbedaan warna kulit, bahasa maupun budaya dan agama. Kemuliaan dan tinggi rendahnya martabat seseorang dapat diperoleh siapa saja, tidak pandang dia berkulit hitam atau berkulit putih karena kemuliaan seseorang ditentukan oleh ilmu yang dimiliki dan amal perbuatan.

Islam menjunjung tinggi kesamaan derajat manusia. Pemikir Islam, Nur Cholis Madjid, mengatakan dalam agama Islam ajaran egalitarianisme kuat sekali. Tidak ada agama yang sedemikian kuat dari pada agama Islam dalam hal persamaan manusia. Dalam sumber ajaran Islam baik dari Alquran maupun Hadis telah banyak ditemukan nilai-nilai luhur ajaran agama yang sangat sesuai dengan fitrah kemanusiaan.

\section{Tolong Menolong}

Manusia sebagai makhluk individu tidak akan pernah lepas dari lingkungan social dimana ia tinggal dan berada. Tidak mungkin manusia hidup tanpa keterlibatan dan pengaruh dari manusia yang lain. Kehidupan social yang rukun dan damai akan terwujud apabila dalam anggota masyarakat saling memperhatikan dan tolong-menolong. Tolong menolong dalam ajaran Islam adalah ajaran yang fundamental bagi manusia selaku makhluk social. Di antara ayat Alquran yang membahas tentang tolong menolong adalah penggalan dari ayat ke-2 surat al-Maidah;

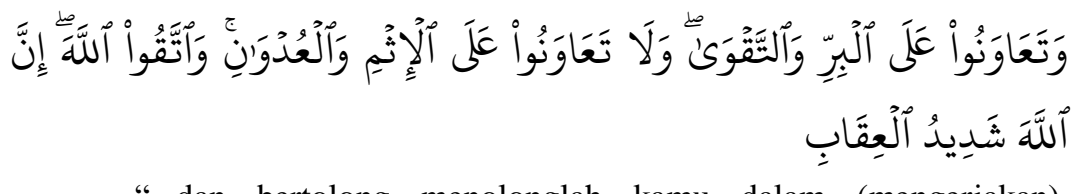

“...dan bertolong menolonglah kamu dalam (mengerjakan) kebajikan dan takwa, dan jangan tolong menolong dalam berbuat dosa dan pelanggaran. Dan bertakwalah kamu kepada Allah, sesunnguhnya Allah amat berat siksanya". 


\section{Pesan Damai Al-Qur'an}

Tolong menolong adalah prinsip dasar dalam menjalin kerjasama dengan siapapun diantara anggota masyarakat, selama tujuannya adalah kebajikan. Kebajikan dalam konteks bermasyarakat adalah segala bentuk dan macam hal yang membawa kemaslahatan bersama. Karena dalam masyarakat pasti akan terdapat anggota masyarakat yang berlainan latar belakang, termasuk latar belakang agama, maka wujud dari bentuk kemaslahatan bersama haruslah berdasarkan partisipasi bersama tanpa mempermasalahkan agama dan kepercayaan.

\section{Keadilan}

Adil dalam bahasa Indonesia adalah hasil adopsi dari Bahasa Arab "al'adl”. Ketika membahas tentang keadilan, dalam Kitab Suci Alquran disebut dalam berbagai bentuk. Selain kata 'adl untuk makna keadilan dengan berbagai nuansanya, Al-quran juga menggunakan perkataan "qisth" dan "wasth". Beberapa pakar tafsir ada yang memasukkan sebagian dari kata "mizan” ke dalam pengertian "'adl”. Semua pengertian berbagai katakata itu bertemu dalam suatu ide umum "sekitar sikap tengah yang berkeseimbangan yang jujur".

Beberapa ayat dalam Alquran berbicara dengan tema keadilan, diantaranya dalam ayat ke 8 surat al-Maidah:

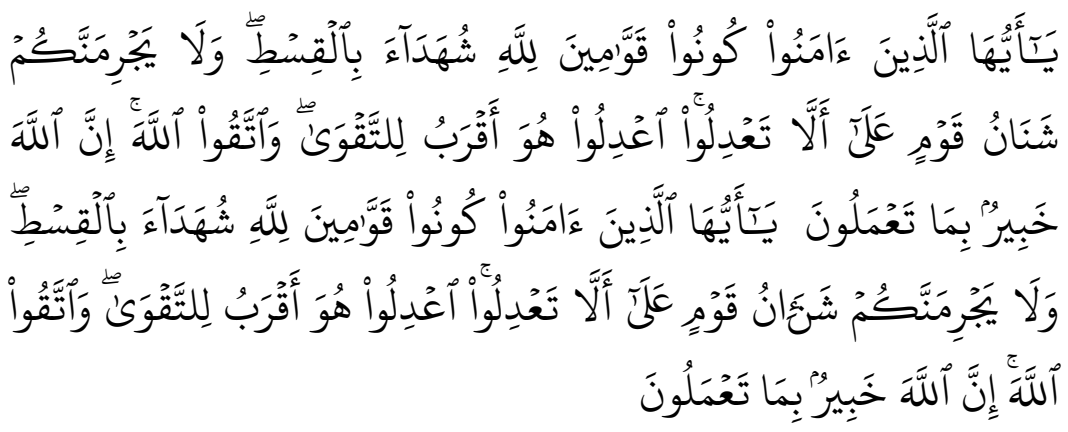

"hai orang-orang yang beriman, hendaklah kamu menjadi Qawwamin karena Allah, menjadi saksi dengan adil. Dan janganlah sekali-kali kebencian kamu terhadap suatu kaum, mendorong kamu untuk berlaku tidak adil. Berlaku adillah, karena ia lebih dekat dengan takwa. Dan bertakwalah kepada Allah sesungguhnya Allah Maha Mengetahui apa yang kamu kerjakan". 
Dengan tegas dinyatakan dalam ajaran Alquran bahwa adil lebih dekat dengan takwa. Ayat lain berbicara tentang keadilan ada dalam ayat ke-90 surat an-Nahl:

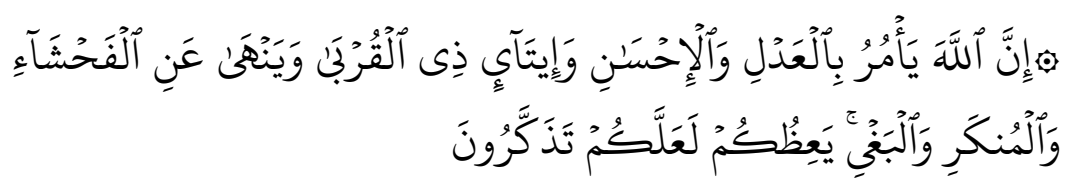

"sesungguhnya Allah memerintah kamu berlaku adil dan berbuat kebajikan, member kepada kaum kerabat, dan Allah melarang dari perbuatan keji, kemungkaran dan permusuhan. Dia member pengajaran kepadamu agar kamu dapat mengambil pelajaran"

Dalam ayat ke-135 surat an-Nisa juga membahas tema keadilan:

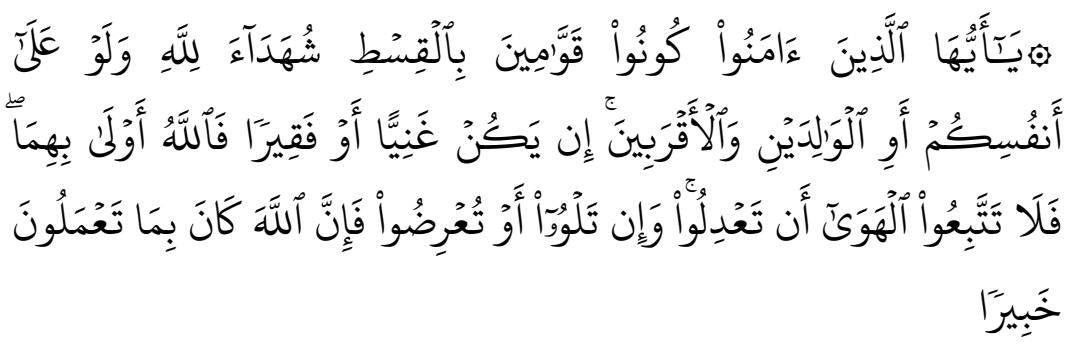

"wahai orang-orang beriman, jadilah kamu orang-orang yang tegak untuk keadilan, sebagai saksi bagi Allah walaupun mengenai diri kamu sendiri, atau kedua orang tuamu dan karib-kerabat. Kalau (mengenai) orang kaya atau miskin, maka Allah lebih mampu melindungi keduanya. Karena itu janganlah kamu mengikuti hawa nafsu dalam menegakkan keadilan. Dan kalau kamu menyimpang atau berpaling (dari keadilan) maka sesungguhnya Allah Maha Mengetahui apa yang kamu kerjakan".

Ayat-ayat tersebut di atas, memberikan yang begitu mendalam betapa kuatnya aspirasi keadilan dalam Islam. Keadilan adalah merupakan kata yang menunjuk substansi ajaran Islam. Jika ada satu kata yang dipilih untuk menggambarkan substansi ajaran Islam, maka kata itu adalah 'adil”. Adil adalah meletakkan segala sesuatu pada tempat sebagaimana mestinya (Shihab, 2002: 42/jilid III). Jika seseorang memerlukan kasih, maka dengan berlaku adil kita dapat mencurahkan kasih kepadanya. Jika seseorang melakukan pelanggaran dan wajar mendapat sangsi maka ketika itu dituntut menjatuhkan hukuman setimpal atasnya. 


\section{Pesan Damai Al-Qur'an}

\section{Menumbuhkan Kesadaran Multikuralisme}

Sebagai sebuah paham, multikulturalisme relatif baru. Paham ini muncul pada decade 70-an di Amerika, Kanada, Inggris dan Australia. Multikuralisme digunakan oleh pemerintah untuk mengatur pluralitas etnik dalan menentukan kebijakan public. Pemerintah Kanada, pada tahun 1965, mengeluarkan kebijakan multikulturalisme, setelah mempertimbangkan pesatnya arus imigrasi dan mengacu pada undang-undang yang berkaitan dengan keyakinan yang di dalamnya memberikan perhatian terhadap nilai persamaan, toleransi dan inklusivisme terhadap kelompok pendatang dari berbagai etnis.

Di Inggris, pada tahun 1998, dibentuk Komisi Masa Depan Multietnis yang mempromosikan keadilan ras dan masyarakat multikultural. Menguatnya arus imigrasi yang datang dari banyak Negara dengan perbedaan budaya telah menempatkan multikulturalisme sebagai kebijakan politik. Sementara di Amerika Serikat, multikulturalisme dilakukan oleh kalangan radikal kiri dalam rangka mengkritisi bias eropasentrisme. Dalam hal ini, yang paling mencolok adalah munculnya gerakan dari etnis Afrika yang meminta agar meletakkan kebudayaan Afrika di samping budaya Amerika dan sejarah barat. Mereka juga meminta agar mendapatkan penghargaan dan hak pendidikan bagi orang-orang Afrika di Amerika. Sehingga dalam hal ini multikulturalisme tidak hanya sekedar menjadi paham yang memproteksi hak-hak minoritas, tetapi juga sebagai perlawanan terhadap ketidakadilan yang dilakukan oleh pemerintah, terutama terhadap kelompok-kelompok minoritas.

Sebagai sebuah paham, multikulturalisme memberikan perhatian kepada kelompok-kelompok minoritas, terutama dalam melindungi kelompok etnis sehingga mereka dapat mempertahankan identitas yang mereka miliki. Dalam pengertian lain, multikulturalisme adalah nasionalisme untuk minoritas (nationalism of the minorities). Dalam perkembangan selanjutnya, multikulturalisme telah memberikan sumbangsih yang amat besar bagi tumbuhnya kesadaran akan penntingnya 
perlindungan kelompok minoritas. Dalam pengalaman Negara-negara yang menganut system demokrasi, pada umumnya mempunyai kesadaran yang sangat tinggi terhadap pentingnya multikuralisme untuk membangun toleransi, asimilasi dan persamaan hak diantara warga Negara. Rasulullah memberikan sebuah pesan yang sangat menarik; "wahai manusia, bukankah Tuhan kalian satu, sesungguhnya bapakmu sekalian itu satu, bukankah tidak keistimewaan antara orang-orang Arab dengan orangorang asing, dan antara orang asing dengan orang Arab, tidak pula untuk orang berkulit merah atas orang berkulit hitam, dan tidak pula orang berkulit putih atas orang berkulit merah, kecuali takwa kepada Allah SWT. (HR. Imam Ahmad).

Dalam tafsir al-Munir, Wahbah Zuhaily mengutip hadis riwayat Muslim dan Ibnu Majah dari Abu Hurairah ra. Rasulullah SAW. Bersabda: "sesungguhnya Allah tidak melihat kepada warnamu dan harta kekayaannmu tetapi melihat kepada hati dan amal perbuatanmu”. Dalam hadis yang lain, at Thabrany, meriwayatkan hadis dari dari Abu Malik alAsy'ary, Rasulullah SAW. Bersabda: "sesungguhnya Allah tidak melihat kepada kedudukanmu, juga tidak melihat nasabmu, juga tidak melihat ragamu, dan juga tidak melihat harta kekayaanmu, tetapi melihat kepada hatimu. Maka apabila dia mempunyai hati yang baik, Allah akan menyayanginya. Kalian semua adalah anak Adam, dan yang paling dicintai Allah adalah yang paling bertakwa kepadanya". Hadis-hadis yang dikutip di atas memberikan pesan yang teramat jelas bagi manusia agar kehidupan berjalan dalam suasana saling menghormati, meskipun secara alamiah (sunnatullah) terdapat perbedaan-perbedaan etnis, budaya, keyakinan, kedudukan dan perbedaan-perbedaan lainnya. Keluarga Rasulullah sendiri merupakan tipe keluarga dengan nuansa multikultural yang kental. Rasulullah tidak hanya memperistri wanita dari ras Arab saja, tetapi juga menikahi wanita dari ras lain. Diantara istri Rasulullah ada yang berdarah Yahudi. Shafia binti Huyay adalah keturunan bangsawan Yahudi yang kemudian memeluk Islam. Selanjutnya ada Maria binti Sam'un, wanita 


\section{Pesan Damai Al-Qur'an}

berdarah Qibthi yang berasal dari Mesir. Istri-istri Rasulullah tersebut setia mendampingi hingga beliau wafat. Disamping itu terdapat banyak sekali orang-orang yang dekat dengan Rasulullah. Selain para istri, beliau juga memiliki pembantu-pembantu yang berasal dari latar belakang suku, budaya, bahasa, serta warna kulit yang berbeda-beda.

Ketika periode Madinah, dalam rentan waktu yang tidak terlalu lama, Rasulullah SAW. Berhasil mempersatukan kelompok masyarakat dan kabilah yang berada di Madinah dan sekitarnya. Diantara mereka terdapat tradisi dan agama yang berbeda-beda yang kemudian disatukan dalam satu "kontrak politik" untuk menjalani kehidupan yang rukun, damai, saling menghormati dan menjaga keamanan madinah di tengah keragaman baik etnis maupun agama. Tetapi di lain sisi, setiap anggota masyarakat mendapat hak dan kebebasannya dalam menjalankan tradisi dan praktik keagamaan. Kontrak politik itu kemudian disebut juga dengan "mitsaq madinah" atau Piagam Madinah yang harus dipatuhi bersama. Diantara butir-butir piagam madinah, antara lain, di antara mereka harus saling tolong-menolong; kaum Muslim dan Kaum Yahudi menyediakan dana keamanan bersama; penganut Muslim dan Yahudi bebas melakukan keagiatan-kegiatan keagamaan tanpa saling mengganggu satu dengan lainnya; masing-masing kelompok menjaga kejujuran dan loyalitas dalam kehidupan bersama; apabila terjadi sengketa dan perselisihan, maka akan diadukan masalahnya kepada Rasulullah yang akan memberi putusan dengan adil.

\section{E. Penutup}

Ajaran agama Islam yang bersumber dari Alquran adalah ajaran mengajarkan kasih sayang dalam setiap kehidupan manusia. Dengan menampilkan wajah lembut penuh kasih sayang, justru akan semakin terlihat keluhuran ajaran Islam. Salah persepsi terhadap ajaran Islam adalah karena ulah sebagian kelompok dalam Islam yang menampilkan ajaran Islam ke permukaan dengan wajah bengis yang kurang bersahabat dengan kelompok agama lain. Ayat-ayat dalam Alquran dikaji dengan pendekatan 
tekstual(Skripturalis) sesuai dengan kepentingan kelompoknya. Pada titik tertentu, kelompok dari agama lain mengalami ketakutan terhadap Islam. Hal ini kemudian menjelma menjadi gerakan anti Islam (Islamophobia) yang banyak terjadi di masyarakat barat.

Sudah saatnya teks-teks suci keagamaan yang mengajarkan tentang nilai-nilai luhur dalam kehidupan bermasyarakat digali kembali untuk kemudian didengungkan terus-menerus guna mencapai kehidupan umat manusia yang beradab. Ayat Alquran sebagai firman Tuhan yang ditujukan kepada umat manusia, tentulah ajarannya sesuai dengan fitrah kemanusiaan yang menghendaki hidup dalam kedamaian. Keragaman yang ada dalam banyak lini kehidupan manusia adalah sunnatullah yang sudah sering dibahas dalam Alquran. Keragaman haruslah menjadi factor penguat dan perekat antar manusia apapun latar belakang agama dan preferensi ideologinya, bukan menjadi factor permusuhan dan tercabiknya persatuan antar sesame manusia. 


\section{Pesan Damai Al-Qur'an}

\section{Daftar Pustaka}

Al-Munawwar, Said Agil Husin. 2003. "Fikih Hubungan Antar Agama”. Jakarta: Ciputat Press.

Alquran dan Terjemahnya. 1995. Departemen Agama R.I.

Hick, John. 2006. “Tuhan Punya Banyak Nama”. Yogyakarta: Institut DIAN/Interfidei.

Imam Muhammad al-Razi Fakhruddin ibn Allamah Dyiyauddin Umar. 1993. “Tafsir al-Kabir wa Mafatih al-Ghayb”. Beirut: Dar al-Fikr.

Lopa, Baharuddin. 1996. “Alquran dan Hak-Hak Asasi Manusia”. Yogyakarta: Dhana Bakti Prima Yasa.

Munawar-Racman, Budhy. 2006. “Ensiklopedi Nurkholis Madjid”. Bandung: Mizan.

Noer Zaman, Ali (ed). 2000. “Agama Untuk Manusia”. Yogyakarta: Pustaka Pelajar.

Misrawi, Zuhairi. 2007. “Alquran Kitab Toleransi: Inklusivisme, Pluralisme, dan Multikulturalisme. Jakarta: Penerbit Fitrah.

Shihab, M. Quraish. 2002 "Tafsir al-Mishbah: Pesan, Kesan dan Keserasian al Qur'an”, Volume I, III, IX dan XIII . Jakarta: Lentera Hati.

Shihab, M. Quraish. 1996. “Wawasan Alquran: Tafsir Tematik atas Pelbagai Persoalan Umat”. Bandung: Mizan.

Tholhah Hasan,Muhammad.2016. Pendidikan Multikultural sebagai Opsi Penanggulangan Radikalisme. Malang: Lembaga Penerbitan Universitas Islam Malang. 